\title{
Oxygen Consumption of Nauplii of Marine Planktonic Copepods
}

\author{
Gustav-Adolf Paffenhöfer ${ }^{1 *}$ and Marion Köster ${ }^{2}$ \\ ${ }^{1}$ Skidaway Institute of Oceanography, USA \\ ${ }^{2}$ Ernst-Moritz-Arndt Universität Greifswald, Germany \\ *Corresponding author: Gustav Adolf Paffenhofer, Skidaway Institute of Oceanography, 10 Ocean Science Circle Savannah, Georgia 31411, USA

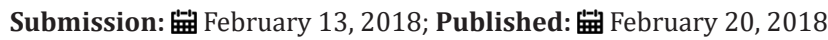

\begin{abstract}
The objective of our study was to determine the oxygen consumption rates of nauplii of two small calanoid species, Paracalanus quasimodo and Temora turbinata, and compare their rates with those of three other planktonic species. The comparisons reveal that motion results in higher oxygen consumption i.e. higher energy expenditure than little or no motion. In addition, the type of motion results in different oxygen consumption rates, and therefore different energy expenditures. Our findings also show that nauplii consume more energy per unit body weight than their copepodids. This implies that small calanoid nauplii, having few energy reserves, are at a disadvantage in relation to copepodid stages as they require continuous food supply and continuous feeding which here is accompanied by continuous motion. That leaves them vulnerable to predators. Thus, not only predation but also discontinuous/intermittent feeding activity could result in increased mortality of calanoid nauplii.
\end{abstract}

Keywords: Copepod nauplii; Oxygen consumption; Metabolism

\section{Introduction}

Marine planktonic copepods are the most abundant metazoa on our planet [1]. Within this taxon the early juveniles, the nauplii, are the most abundant. So far, the vast majority of research on planktonic copepods has been on late juveniles and adult stages i.e. nauplii were rarely included [2]. In his Biology of Calanoid Copepods of 710 pages devoted about 1\% (less than 10 pages) to nauplii. More than four decades ago the significance of copepod nauplii was addressed within process studies on calanoid copepods: [37] since nauplii of planktonic copepods usually do not accumulate energy reserves as copepodid stages and adults do [8] they most likely will not survive food shortages over longer periods of time. Yet our knowledge on their food requirements and energy needs is limited $[9,10]$. Studies in temperate waters revealed that in situ mortality of nauplii and older stages is related to invertebrate and vertebrate predators $[11,12]$. We know from laboratory studies that survival of nauplii and older stages of calanoid is also a function of food abundance [5]. So far, our knowledge of nauplius mortality in relation to food abundance in warmer waters is scarce. We know that energy consumption per unit body weight decreases from younger to older stages of copepods $[10,13]$. The goal of this study was to quantify the oxygen consumption rate of two species of small calanoid copepods, Paracalanusquasimodo and Temoraturbinata which often occur abundantly on the U.S. southeastern continental shelf [14] and compare their rates to those of other planktonic copepod species, and with older stages. We calculated their daily energy requirements by transforming oxygen consumption into energy units and compared this with their food intake assuming 93\% assimilation efficiency [9].

\section{Material and Methods}

\section{Rearing of nauplii}

Late copepodid stages and adult females were collected from the U.S. southeastern continental shelf during summer of 2007 and late winter 2008 (Temora turbinata), and January/February 2015 and March 2016 (Paracalanus quasimodo). The copepodid stages moulted to adults followed by egg production. Eggs were also obtained from the collected females (age unknown) which had a short reproductive period (age unknown). Rearing occurred at 19.5 to $20.1{ }^{\circ} \mathrm{C}$ during $12 \mathrm{~h}$ dim light/12h darkness in glass vessels of 960 to $1,900 \mathrm{ml}$ volume on a plankton wheel rotating at $0.5 \mathrm{rpm}$. The nauplii were offered simultaneously the flagellates Isochrysis galbanaand Rhodomonas sp. and the diatom Thalassiosira weiss

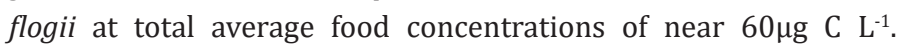
This approach provided food levels close to frequently $60 \mu \mathrm{g} \mathrm{C} \mathrm{L}^{-1}$ occurring phytoplankton abundances on the middle to outer shelf. The jars were inspected daily and the concentrations of each of the three food species were determined by using a Beckman-Coulter Multisizer IV. At the beginning of each experiment additional food particles were added to reach food levels of near 20-30\% higher than the average food concentration (Table 1). 
Table 1: $\mathrm{O}_{2}$ Consumption rates, weight-specific respiration and ingestion of different planktonic copepods. Rho Rhodomonas sp., Thw Thalassiosira weissflogii.

\begin{tabular}{|c|c|c|c|c|c|c|c|c|c|}
\hline \multirow[t]{2}{*}{ Species } & \multirow[t]{2}{*}{ Stage } & \multirow[t]{2}{*}{ Weight } & \multirow[t]{2}{*}{ Temperature } & \multicolumn{2}{|c|}{ Average Food } & \multirow{2}{*}{$\begin{array}{c}\begin{array}{c}\mathbf{O}_{2^{-}}^{-} \\
\text {Consumption }\end{array} \\
\text { respiration }\end{array}$} & \multicolumn{2}{|c|}{ Weight-Specific } & \multirow[t]{2}{*}{ References } \\
\hline & & & & concentration & $\begin{array}{c}\text { Food } \\
\text { species }\end{array}$ & & respiration & ingestion & \\
\hline & & (ng C) & ${ }^{\circ} \mathrm{C}$ & $\left(\mu \mathrm{g} \mathrm{CL}^{-1}\right)$ & & & $\left(\mathrm{nl} \mathrm{0} \mathrm{O}_{2} \mathrm{~d}^{-1}\right)$ & & \\
\hline \multirow[t]{2}{*}{$\begin{array}{l}\text { Oithona } \\
\text { davisae }\end{array}$} & N III/N IV & 55 & 20 & no food & & 21 & 16.4 & n.d. & \\
\hline & & & & & & 46 & 36 & n.d. & $\begin{array}{l}\text { Almeda et } \\
\text { al. [8] }\end{array}$ \\
\hline $\begin{array}{c}\text { Eucalanus } \\
\text { pileatus }\end{array}$ & N IV-N VI & $480-990$ & 21.5 & 61 & & $430-720$ & 29.7 & 17.7 & $\begin{array}{c}\text { Köster et al. } \\
\text { [7] }\end{array}$ \\
\hline $\begin{array}{c}\text { Paracalanus } \\
\text { quosimodo }\end{array}$ & N IV-N VI & $40-71$ & 21.5 & 22.3 & Rho & 95 & 71.1 & 67.6 & This study \\
\hline $\begin{array}{l}\text { Temora } \\
\text { turbinata }\end{array}$ & N III-N VI & $67-157$ & 21.5 & 9.1 & Thw & 91 & 33 & 24.1 & This study \\
\hline
\end{tabular}

\section{Fluorescence-based oxygen quantification}

The oxygen consumption of nauplii of the calanoid copepods P. quasimodo and T. turbinata was quantified using optical fluorescence-based oxygen respirometry [15]. A 24-channel Sensor Dish Reader (SDR, Presens, Regensburg, Germany) was used to quantify oxygen consumption in $8 \mathrm{ml}$ and $10.5 \mathrm{ml}$ respiration chambers containing nauplii and food. Changes in oxygen concentrations were recorded continuously at 5-minute intervals over 4 to $6 \mathrm{~h}$ i.e. in time-series. All oxygen measurements were performed in darkness. For further information [9]. All experiments were run at 21.5 to $21.8{ }^{\circ} \mathrm{C}$.

\section{Nauplii experiments}

The oxygen consumption experiments with nauplii of $T$. turbinata were run in September 2007 and March 2008, and those with nauplii of P. quasimodo in March 2015 and September 2016, all at a temperature of $21.5^{\circ} \mathrm{C}$. The T. turbinate studies occurred in standing vials of $10.5 \mathrm{ml}$ volume with the number of nauplii ranging from 39 to 65 per vial; stages ranged from N III to N VI, weighing 67 to $157 \mathrm{ng}$ C. We decided to offer food at environmental abundances because the absence of food would result in an underestimation of metabolic rates of copepods [10]. The food species was T. weissflogii $(1,000$ to $1,200 \mu \mathrm{m} 3$ cell volume). The more recent studies with nauplii of $P$. quasimodo were conducted in $8.0 \mathrm{ml}$ vessels being on a plankton wheel rotating at $0.5 \mathrm{rpm}$. The number of nauplii per vial ranged from 39 to 64 weighing on average 40 to $71 \mathrm{ng} \mathrm{C}$ Nauplius $^{-1}$ (N IV to N VI). Here the food was Rhodomonas sp. (300 to $350 \mu \mathrm{m}^{3}$ cell volume); and later Isochrysis galbana $\left(40 \mu \mathrm{m}^{3}\right.$ cell volume). Four vials, serving as controls, were always run simultaneously. The control vessels had the same phytoplankton species and concentration as were offered to the nauplii. The oxygen consumption by the nauplii in each vessel was quantified from the linear part of the time-series oxygen concentration data by linear regression. The nauplius' individual respiration rate was quantified by subtracting the average rates in the control vials from the individual respiration rates in order to eliminate the net oxygen consumption or production by bacteria and phytoplankton. The daily metabolic expenditures per Nauplius were calculated as $1 \mathrm{nl}$ oxygen respired $=0.43 \mathrm{ng} \mathrm{C}$ respired [4].

After the oxygen time-series experiments the nauplii's morphology and motion behavior were inspected under a dissecting microscope. The contents of each vial were placed in a settling chamber, preserved with $2 \%$ Lugol's solution to count the remaining phytoplankton cells. Initial and final phytoplankton concentrations served to calculate clearance and ingestion rates of all nauplius experiments [16]. Each nauplius' body length was measured to obtain an average weight (ng C) from a previously obtained regression of Nauplius length vs. weight for each of the two copepod species: P. quasimodo $\log \mathrm{y}=2.088 \log \mathrm{x}-2.921 ; T$. turbinata $\log \mathrm{y}=3.195 \log \mathrm{x}-5.446$.

\section{Statistics}

We calculated linear regressions of Nauplius weight (ng C Nauplius $^{-1}$ ) vs. oxygen consumption (nl oxygen respired Nauplius ${ }^{-1}$ $\mathrm{h}^{-1}$ ), and then compared slopes and elevations [17].

\section{Oxygen consumption}

Nauplii of T. turbinate which create a feeding current and move slowly at $0.5 \mathrm{mms}^{-1}$ [18] consumed $2.15 \mu \mathrm{l} \mathrm{h}^{-1}$ while those of P. quasimodo of the same weight (70ng C), moving continuously at $1.34 \mathrm{mms}-1$ consumed $4.5 \mathrm{nl} \mathrm{h}-1$ i.e. over $100 \%$ more than $T$. turbinatanauplii. Nauplii of Oithonadavisae of the same weight but without food consumed only $1.1 \mathrm{nl} \mathrm{O}_{2}{ }^{-1} \mathrm{~h}^{-1}$ at $20^{\circ} \mathrm{C}$ [10]. It appears that oxygen consumption increased with increased motion as shown earlier for adult female copepods [19]. The fast-moving females of Clausocalanus furcatus consumed about $65 \%$ more oxygen than the slowly-moving and feeding current-producing Paracalanus aculeatus females [10]. Also determined oxygen consumption of $O$. davisae nauplii at the extraordinarily high food concentration of $2.75 \mathrm{mg} \mathrm{C} \mathrm{L}^{-1}$ resulting in an $\mathrm{O}_{2}$ consumption increase by factor 2.3 i.e. $2.5 \mathrm{nl} \mathrm{O}_{2} \mathrm{~h}^{-1}$ of a $70 \mathrm{ng} \mathrm{C}$ Nauplius. Such an increase in oxygen consumption is thought to be associated with Specific Dynamic Action (SDA) which has been related to the expense associated with biosynthesis of new tissue from recent ingestion [20]. They 
showed that respiration of the copepod Acartia tonsa increased with markedly increasing ingestion. We intentionally offered food near environmental levels in our experiments because of our generally environmentally-oriented research. This implies that no experiments were conducted without food. We are also comparing our findings with those of [21] on non-feeding copepods because the taxa we used in our experiments were part in their metabolic rate quantifications (Temora turbinata and the genus Paracalanus). Their equation of oxygen consumption vs. body carbon at $21.5^{\circ} \mathrm{C}$ gives a value of $3.0 \mathrm{nl} \mathrm{O}_{2} \mathrm{~h}^{-1}$ for a copepod of $70 \mathrm{ngC}$, ranging between our values of T.turbinata and P. quasimodo. Would there be no food shortage effects of oxygen consumption by starving copepods? At $20{ }^{\circ} \mathrm{C}$ O.davisae nauplii without food are lowering their oxygen consumption rate $10 \mathrm{~h}$ after starting the experiment, implying that immediate effects of food absence were not observed (Figure 1). It appears that oxygen consumption rates of copepods measured for several hours just after they were removed from their food are close to those or even identical as when they were feeding.

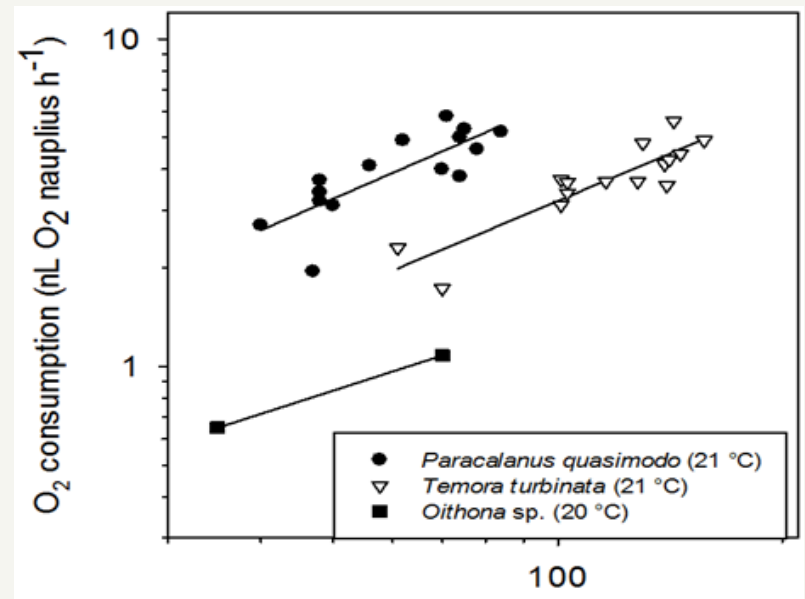

Body weight ( $\mu \mathrm{g} \mathrm{C})$

Figure 1: Oxygen consumption in relation to body weight of nauplii of three species of planktonic copepods. (O.davisae data from Almeda et al. [8]). Regression equations:

Oithona davisae

$\log \mathrm{y}=0.766 \log \mathrm{x}-1.376$

Temora turbinata

$\log \mathrm{y}=1.028 \log \mathrm{x}-1.554$

Paracalanus quasimodo

$\log \mathrm{y}=1.013 \log \mathrm{x}-1.175$

\section{Significance of metabolic expenditures and behaviors} for copepod nauplii and older stages

When comparing metabolic expenditures of the various juvenile stages of planktonic copepods it became apparent that expenditures per unit body weight decrease with increasing stage [10]. Nauplii of many calanoid species are at an evolutionary disadvantage because they not only have a higher metabolic demand than their older brethren but also have to find food by moving continuously, thus leaving them exposed to predators. In addition, their mechanosensory performance is inferior to that of the copepodid stages as shown by results from [22] late nauplii of the genera Paracalanus and Acartia were more heavily preyed upon than early copepodids of the same species by the females of the carnivorous calanoid Labidocera trispinosa. While the nauplii of T. turbinata and P. quasimodo are moving all their appendages and setae continuously their copepodid stages possess the nonmoving first antennae with 3-D oriented setae at their tips which perceive oncoming predators, and thus avoid heavy predation. While we observe a major change in morphology from Nauplius VI (N VI) to copepodid stage I (C I), particularly for the first antennae (A1), there can be no change in motion behavior, e.g. the genus Temora producing continuously feeding currents, which should be accompanied by hardly any change in oxygen consumption from $\mathrm{N}$ VI to C I (as their weights hardly differ). Or, a major change is observed as for the genus Paracalanus where the nauplii move hopwise continuously fast whereas the copepodid stages produce a feeding current and moving slowly [18] which should result in less energy expenditure.

The opposite is observed for the cyclopoid Mesocyclops brasilianus: Here the nauplii hardly move; right after moulting the C I moves continuously consuming $250 \%$ more oxygen than the $\mathrm{N}$ VI of about the same weight [18]. Are there any in situ indications that nauplii may suffer higher mortality than their older stages in continental shelf waters? Time-series observations during summer of 1978 were made possible by following a drogue in up welled water over 10 days sampling each vertical layer (warm upper mixed layer=UML, thermocline $=\mathrm{TH}$, and intruding cold up welled water mass= IN) with 100 and 30 micron mesh. This allowed quantitative sampling of nauplii and older stages of abundant copepods [24]. The average concentrations of nauplii of T. turbinata of 7 stations was 6067,3903 and $3244 \mathrm{~m}^{-3}$ in the UML, TH and IN, respectively. The average concentrations of copepodids and adults of the same species were only 641, 1042, and $1873 \mathrm{~m}^{-3}$, respectively. At each depth range of each of the 7 stations the concentrations of the nauplii surpassed those of the older stages clearly. From those data the probability of substantial mortality of nauplii cannot be excluded, as compared to the post naupliar stages. The question then would remain whether food and/or predators were the cause. During autumn the omnivorous calanoid Centropages velificatus intermittently dominates on the southeastern middle shelf while the often dominant mainly herbivorous $P$. quasimodo hardly occurs (unpubl. results). It is assumed that the strongly carnivorous omnivore [25] affects the P. quasimodo assemblage by consuming its nauplii.

The relatively high metabolic rates of the nauplii (near 33\% of body C for T. turbinata, and $69 \%$ for P. quasimodo) require near continuous food supply because these nauplii have hardly any energy reserves which older stages have [8]. Will there be a continuously sufficient food supply on the SE shelf during much of the year? Since the range of perception and ingestion is limited for those small nauplii, mainly in the range of 4 to 11 microns (pers. obs.), and competition is provided by heterotrophic dinoflagellates and mixotrophs, sufficient food concentrations may not always be found [26]. Analyzed the effects of starvation on nauplii of Calanus pacificus: when initial feeding was delayed for about $10 \mathrm{~h}$ after moulting to N III survivorship was reduced. For well-feeding stages 
of N III to N VI survival was reduced when starving for more than $6 \mathrm{~h}$ However, complete starvation may not often occur, as abundances of phytoplankton will never be below $0.04 \mu \mathrm{g}$ chlorophyll $\mathrm{L}^{-1}$ [19] i.e. about $2 \mu \mathrm{g} \mathrm{C} \mathrm{L}^{-1}$. However, major reductions of small phytoplankton will occur on the SE shelf as e.g. abundances of more than 5,000 $P$. quasimodo copepodids/adult females were intermittently encountered which would substantially reduce cells in the range of 5 to $12 \mu \mathrm{m}$ ESD (Equivalent Spherical Diameter and Paffenhöfer, unpubl. results).

At which food concentrations will nauplii of T. turbinate and $P$. quasimodo meet their metabolic expenditure? In our oxygen consumption experiments the weight-specific ingestion rate of T. turbinata nauplii was $24.1 \%$ at an average food concentration of $9.1 \mu \mathrm{g} \mathrm{C} \mathrm{L}^{-1}$ of $T$. weissflogii while the respiration expenditure was $33 \%$ of its body carbon. In jars of 480 and $960 \mathrm{ml}$ capacity $T$. turbinate nauplii ingested daily $36 \%$ of their body carbon at $10 \mu \mathrm{g} \mathrm{C}$ $\mathrm{L}^{-1}$ of T. weissflogii (unpubl. results). It appears that the small oxygen consumption vessels of $10.5 \mathrm{ml}$ capacity, and the not-moving, could have affected the nauplii's ingestion rates. Nauplii of $P$. quasimodo, being smaller, were studied in vessels of $8.0 \mathrm{ml}$ capacity, starting at higher food concentrations (flagellate Rhodomonas sp.) than for $T$. turbinata, being mounted on a slowly-moving plankton wheel. At an average food concentration of $22.3 \mu \mathrm{C} \mathrm{C} \mathrm{L}^{-1}$ those nauplii ingested Rhodomonasat a rate of $71 \%$ of their body carbon $\mathrm{d}^{-1}$ while respiring $69 \%$ daily at $21.6^{\circ} \mathrm{C}$. When feeding on T. weissflogiiat $20^{\circ} \mathrm{C}$ at about $8 \mu \mathrm{g} \mathrm{C} \mathrm{L}^{-1} \mathrm{a}$ N VI of Paracalanus sp. ingested daily near $70 \%$ and at $24 \mu \mathrm{g} \mathrm{C} \mathrm{L-1} \mathrm{near} 105 \%$ of its body carbon. That occurred in vessels of $960 \mathrm{ml}$ [28] where hardly any wall effects should be encountered. Post naupliar stages spend far less energy per unit body weight than nauplii despite being able to compete with the nauplii for part of the same food: Adult females of Paracalaus aculeatus expend only $15 \%$ of their body carbon per day at $20{ }^{\circ} \mathrm{C}$ [19]. At the same time copepodid stages can accumulate energy reserves; they also are able to vertically explore food reserves more readily than nauplii.

\section{Outlook}

For future studies we plan to record the motion, and feeding of various stages of calanoid copepod species in $100 \mathrm{ml}$ respiration chambers using a sensitive infrared digital camera, and monitor simultaneously the oxygen consumption at environmental food levels (including food limitation) in extended time-series experiments (more than $12 \mathrm{~h}$ ).

\section{Conclusion}

Survival of its nauplii is essential for the persistence of a species. How could we determine survival and associated variables, and find out whether Nauplius losses are caused by predation and/ or food shortage? [29] obtained in Australian river estuaries in situ evidence that the calanoid Gladioferens imparipesis replaced by the omnivorous calanoid Sulcanus conflictus because the latter preys heavily on the nauplii of the former. It appears that on a continental shelf a closely spaced time-series, building on earlier data, would be needed to track a defined body of water in vertical layers over time. Nauplii, copepodid stages and potential predators and associated needed variables would be collected quantitatively [30]. The respective prey species would require to be staged [31-35]. This would be readily possible for each of the two Temora species on the SE shelf [36-40].

\section{Financial Support}

This research was supported by NSF Grant OCE 1031263.

\section{Acknowledgement}

Captain and crew of the R/V Savannah always supported us with competence and can-do attitude. We gratefully acknowledge their support.

\section{References}

1. Fryer G (1986) Structure, function and behavior, and the elucidation of evolution in copepods and other crustaceans. Syllogeus 58: 150-157.

2. Mauchline J (1998) The biology of calanoid copepods. In: Blaxter JHS, Southward AJ, Tyler PA (Ed.), Advances in Marine Biology. Academic Press, San Diego, Boston, New York, London Vol. 33, p. 710.

3. Marshall SM, Orr AP (1956) On the biology of Calanus finmarchicus. IX. Feeding and digestion in the young stages. Journal of the Marine Biological Association of the United Kingdom 35(3): 587-603.

4. Mullin MM, Brooks ER (1970) Growth and metabolism of two planktonic, marine copepods as influenced by temperature and type of food. In: Steele JH (Ed.), Marine Food Chains, Oliver and Boyd, Edinburgh, UK, pp. 74-95.

5. Paffenhöfer GA (1970) Cultivation of Calanus helgolandicus under controlled conditions. Helgoländer wissenschaftliche Meeresuntersuchungen 20: 346-359.

6. Harris RP, Paffenhöfer GA (1976) The effect of food concentration on cumulative ingestion and growth efficiency of two small marine planktonic copepods. Journal of the Marine Biological Association of the United Kingdom 56(4): 875-888

7. Fernandez F (1979) Nutrition studies in the nauplius larva of Calanus pacificus (Copepoda: Calanoida). Marine Biology 53(2): 131-147.

8. Lee RF, Nevenzeland JC, Paffenhöfer GA (1972) The presence of wax esters in marine planktonic copepods. Naturwissenschaften 59(9): 406411.

9. Köster M, Krause C, Paffenhöfer GA (2008) Time-series measurements of oxygen consumption of copepod nauplii. Marine Ecology Progress Series 353:157-164.

10. Almeda R, Alcaraz M, Calbet A, Saiz E (2011) Metabolic rates and carbon budget of early developmental stages of the marine cyclopoid copepod Oithona davisae. Limnology Oceanography 56(1): 403-414.

11. Eiane K, Aksnes DL, Ohman MD, Wood M, Marinussen MB (2002) Stagespecific mortality of Calanus spp. under different predation regimes. Limnology and Oceanography 47(3): 636-645.

12. Eiane K, Ohman MD (2004) Stage-specific mortality of Calanus finmarchicus, Pseudocalanus elongatus and Oithona similis on Fladen Ground, North Sea, during a spring bloom. Marine Ecology Pogress Series 268:183-193.

13. Epp RW, Lewis WM (1980) The nature and ecological significance of metabolic changes during the life history of copepods. Ecology 61(2): 259-264.

14. Bowman TE (1971) The distribution of calanoid copepods off the Southeastern United States between Cape Hatteras and Southern Florida. Smithsonian Contribution to Zoology 9: 1-64.

15. Kautsky H (1939) Quenching of luminescence by oxygen. Transaction of the Faraday Society 35: 216-219. 
16. Frost BW (1972) Effects of size and concentration of food particles on the feeding behavior of the marine planktonic copepod Calanus pacificus. Limnology and Oceanography 17(6): 805-815.

17.Zar JH (1974) Biostatistical analysis. In: Zar JH (Ed.), Biostatistical analysis. Prentice-hall, Englewood Cliffs, US, pp. 620.

18. Paffenhöfer GA, Strickler JR, Lewis KD, Richman S (1996) Motion behavior of nauplii and copepodid stages of marine planktonic copepods. Journal Plankton Research 18: 1699-1715.

19. Paffenhöfer GA (2006) Oxygen consumption in relation to motion of marine planktonic copepods. Marine Ecology Progress Series 317: 187192.

20. Kiørboe T, Møhlenberg F, Hamburger K (1985) Bioenergetics of the planktonic copepod Acartiatonsa: relation between feeding, egg production and respiration, and composition of specific dynamic action. Marine Ecology Progress Series 26: 85-97.

21. Ikeda T, Kanno Y, Ozaki K, Shinada A (2001) Metabolic rates of epipelagic marine copepods as a function of body mass and temperature. Marine Biology 139(3): 587-596.

22. Landry MR (1978) Predatory feeding behavior of a marine copepod, Labidocera trispinosa. Limnology and Oceanography 23(6): 1103-1113.

23. Epp RW, Lewis ML (1979) Metabolic responses to temperature change in a tropical freshwater copepod (Mesocyclops brasilianus) and their adaptive significance. Oecologia 42(2): 123-138.

24. Paffenhöfer GA (1983) Vertical zooplankton distribution on the northeastern Florida shelf and its relation to temperature and food abundance. Journal Plankton Research 5(1): 15-33.

25. Paffenhöfer GA, Knowles SC (1980) Omnivorousness in marine planktonic copepods. Journal Plankton Research 2(4): 355-365.

26. Lopez MDG (1996) Effect of starvation on development and survivorship of naupliar Calanus pacificus (Brodsky). Journal Experimental Marine Biology and Ecology 203(2): 133-146.

27. Paffenhöfer GA Köster M (2005) Digestion of diatoms by planktonic copepods and doliolids. Marine Ecology Progress Series 297: 303-310.

28. Paffenhöfer GA (1984) Food ingestion by the marine planktonic copepod Paracalanus in relation to abundance and size distribution of food. Marine Biology 80(3): 323-333.

Creative Commons Attribution 4.0

International License

For possible submissions Click Here
29. Rippingale, R.J. and Hodgkin, E.P. (1974) Predation effects on the distribution of a copepod. Australian Journal of Marine and Freshwater Research 25: 81-91.

30. Beers JR, Stewart GL (1971) Micro-zooplankters in the plankton communities of the upper waters of the eastern tropical Pacific. Deep Sea Research and Oceanographic Abstracts 18(9): 861-883.

31. Ueda H (1983) Small-scale ontogenetic and diel vertical distributions of neritic copepods in Maizuru Bay, Japan. Marine Ecology Progress Series 35: 65-73.

32. Damkaer DM (2002) The copepodologist's cabinet. In: Damkaer DM (Eds.), The copepodologist's cabinet. American Philosophical Society, Philadelphia, US, pp. 300.

33. Gerritsen J, Strickler JR (1977) Encounter probabilities and community structure in zooplankton: a mathematical model. Journal of the Fisheries Research Board of Canada 34(1): 73-82.

34. Ikeda T (1985) Metabolic rates of epipelagic marine zooplankton as a function of body mass and temperature. Marine Biology 85(1): 1-11.

35. Jahnke RA Craven DB (1994) The influence of organic matter diagenesis on $\mathrm{CaCO}_{3}$ dissolution at the deep-sea floor. Geochimica et Cosmochimica Acta 58(13): 2799-2809.

36. Klekowski RZ, Kukina IV, Tumanseva NI (1977) Respiration in the micro zooplankton of the equatorial upwelling's in the eastern Pacific Ocean. Polish Archives Hydrobiology 24(Suppl): 467-489.

37. Mullin MM, Brooks ER (1967) Laboratory culture, growth rate, and feeding behavior of a planktonic marine copepod. Limnology Oceanography 12(4): 657-666.

38. Paffenhöfer GA Lewis KD (1989) Feeding behavior of nauplii of the genus Eucalanus (Copepoda, Calanoida). Marine Ecology Progress Series 57: 129-136.

39. Turner JT (2004) The importance of small planktonic copepods and their roles in pelagic marine food webs. Zoological Studies 43(2): 255266.

40. Uchima M, Hirano R (1986) Food of Oithona davisae (Copepoda: Cyclopoida) and the effect of food concentration at first feeding on the larval growth. In: Uchima M, Hirano R (Eds.), Food of Oithona davisae (Copepoda: Cyclopoida) and the effect of food concentration at first feeding on the larval growth. Bulletin of the Plankton Society of Japan, Japan 33: 21-28.

\section{Your subsequent submission with Crimson Publishers} will attain the below benefits

- High-level peer review and editorial services

- Freely accessible online immediately upon publication

- Authors retain the copyright to their work

- Licensing it under a Creative Commons license

- Visibility through different online platforms

- Global attainment for your research

- Article availability in different formats (Pdf, E-pub, Full Text)

- Endless customer service

- Reasonable Membership services

- Reprints availability upon request

- One step article tracking system 